
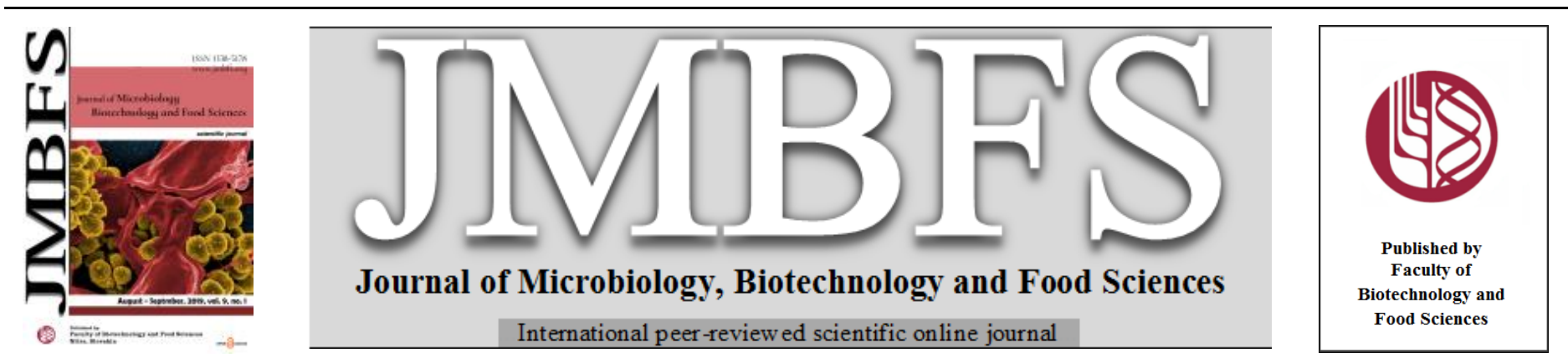

\title{
VISCUM ALBUM PINI EFFECT ON RABBIT SPERMATOZOA MOTILITY, VIABILITY, MEMBRANE AND ACROSOME INTEGRITY IN VITRO
}

\author{
Marko Halo Jr. ${ }^{l}$, Agnieszka Greñ ${ }^{2}$, Natalia Mazur ${ }^{2}$, Tomášs Slanina ${ }^{l}$, Lubomir Ondruška ${ }^{3}$, Grzegorz Formicki ${ }^{2}$, Filip Tirpák ${ }^{1}$, Eduard \\ Kolesár $r^{l}$, Drahomir Galbavý, Peter Massányi ${ }^{1,2}$
}

Address(es): Ing. Marko Halo

${ }^{1}$ Slovak University of Agriculture in Nitra, Faculty of Biotechnology and Food Sciences, Department of Animal Physiology, Tr. A. Hlinku 2, 94976 , Nitra, Slovak Republic.

${ }^{2}$ Pedagogical University of Kraków, Faculty of Geography and Biology, Institute of Biology, ul. Podchorążych 2, $30-084$ Kraków, Poland

${ }^{3}$ National Agricultural and Food Centre, Research Institute for Animal Production Nitra, Institute of Small Farm Animals, Hlohovecká 2, 95141 Lužianky, Slovak Republic

${ }^{4}$ Avelane Clinic, Krčméryho 2B, 949 01, Nitra, Slovak Republic.

*Corresponding author: markohalo@yahoo.com

doi: 10.15414/jmbfs.2019.9.1.144-150

\section{ARTICLE INFO}

Received 7. 12. 2018

Revised 12. 6. 2019

Accepted 12. 6. 2019

Published 1. 8. 2019

Regular article open $\bigodot_{\text {access }}$

\begin{abstract}
Mistletoe (Viscum album L.) was previously described as an effective additive in the therapy of patients with cancer after medical therapy of the primary neoplasia. The defence activity and also direct cytotoxic stimulation was found to be upstanding for the anticarcinogenic action. The main target of this study was to detect the effect of Viscum album pini L. at various concentration 1.0 (PA); $0.66(\mathrm{~PB}) ; 0.33(\mathrm{PC}) ; 0.1(\mathrm{PD}) ; 0.066(\mathrm{PE})$ and $0.033(\mathrm{PF}) \mathrm{mg} / \mathrm{mL}$ on the fine rabbit spermatozoa motility parameters at various time periods $(0 ; 1 ; 2$ and $3 \mathrm{~h})$ during the cultivation in vitro. The CASA methodology was applied to estimate the spermatozoa motility parameters. The spermatozoa motility at the beginning of the experiment (Time 0 ) found decreased rate for examined doses of Viscum album pini compared to the control, but the statistical significant reduction was observed $(\mathrm{p}<0.01)$ only in the sample PD compared to groups PK (control). After 3 hours of in vitro cultivation interesting but not significant tendency of spermatozoa motility increase was found. Only in the group with the highest concentration (PA) a non-significant decrease was detected. Also, other parameters confirm this finding. After 3 hours of incubation, viability of rabbit spermatozoa showed decreased values in all doses of Viscum album pini in comparison to the control group. A significant decrease $(\mathrm{p}<0.01)$ of membrane integrity was found in group PA compared to control group. Also, in groups PB, PC, PD lower values in comparison to control group were detected. Acrosomal integrity showed very similar tendency in all groups. Our results detected any dose and/or time dependent significant effect of Viscum album pini on rabbit spermatozoa motility and viability in vitro. Positive impact on motility parameters after cultivation of rabbit semen with Viscum album pini was not found, but indications of changes on membrane integrity were observed.
\end{abstract}

Keywords: Viscum album pini, spermatozoa, CASA, motility, in vitro

\section{INTRODUCTION}

Herbs have been used widely across cultures for centuries. At the beginning, they were collected, later - cultivated. An important part in herb cultivation was played by Benedictine monks, the Knights Hospitallers and the Capuchin order. A rapid development of pharmacology based on active chemical compound synthesis (started with laboratory preparation of phenacetin by Bayer and pyramidon by Hoechst) significantly diminished the importance of phytotherapy. However, in recent years, the number of ethnopharmacological scientific publications has increased; they analyse agents of plant origin used in traditional medicine (Modak et al., 2007; Greń, 2009; Cravotto et al., 2010; Greń et al., 2011). Nowadays, medical plants are treated as the source of biologically active compounds, which are often extracted on a commercial scale and used in targeted therapies of many diseases. Research outcomes confirm that antioxidants, able to neutralize free radicals, are effective in preventing the development of experimental diabetes in animal models (Kubisch et al., 1997; Naziroglu and Cay, 2001; Karunakaran and Park, 2013).

Viscum album L., the European mistletoe, is an ordinary kind from the Viscaceae family. This usual hemiparasitic bush occurs on different trees and inclused various biologically active substances. Its chemical compound is different depending on the period of gather, species of the host tree and the industrial procedure. Under well-studied and described active phytochemicals identified in $V$. album are lectins and viscotoxins, which perform important part in cancer therapy according to apoptotic and cytotoxic effects. Other parts of compounds occuring in mistletoe are phenolic acids, phenylpropanoids and flavonoids having antioxidant and anti-inflammatory functions. Other mistletoe parts are triterpenes with cytotoxic and apoptotic properties, and phytosterols, oligo- and polysaccharides. Plant extracts, especially aqueous, are being used in traditional and formal medicine, as well as in therapy of hypertension or arthritis. In theory, they can also be used as a hepatoprotective or sedative medicaments (Nazaruk and Orlikowski, 2016).

Systematic reviews of mistletoe therapy (MT) trials in cancer show promising results in improvement of patients' quality of life during chemotherapy and reduction of fatigue. However, patients' experiences of side effects and the acceptability, tolerability, and perceived benefits of MT have not been systematically reviewed. Some patients reported demonstrable changes to their physical, emotional, and psychosocial well-being following MT, as well as a reduction in chemotherapy side effects (Evans et al., 2016).

The mistletoe (Viscum album L.) extract (Iscador) was previously reported as a useful supplementary medication in the therapy of cancer subjects after surgical excision of the primary tumour. This enhanced survival and recovery from injury caused by radiation or cytostatic treatment, as well as the quality of life. In animal experiments, exact anti-carcinogenic action was described (Maldacker, 2006; Gardin, 2009).

Since decades, Viscum album preparations have been used in Europe in oncology. They show multi-facetted anti-tumor in vitro activities, which include inhibition of tumour cell proliferation, induction of apoptosis, inhibition of angiogenesis, modulation of immune competence and gene signature expression. Recently, it was demonstrated in vitro that Viscum album exerts an antiinflammatory effect, mostly directed to chronic inflammation by selectively inhibiting cytokine-induced expression of cyclooxygenase-22 (Seibert $\boldsymbol{e t}$ al., 1989; Bussing, 2006; Bussing et al., 2008; Hegde et al., 2011; Hajto et al., 
2011). It has been stated that anticancer drugs could cause harmful effects on the spermatozoa quality and spermatogenic cell arrangement of male.

Rabbits were chosen as the experimental animal in this research for their well defined reproductive systems (Paál el al., 2014; Rafay and Parkányi, 2016) Some herbal extracts have been proven to have effects on male infertility, for example, gossypol, papaya seed and neem oil and neem seed (Mosher and Pratt, 1991; Dehghan et al., 2005; Roychoudhury et al., 2009). For the in vitro effects of Viscum album on rabbit/animal spermatozoa in order to assess possible beneficial and/or toxic effects of this compound are completely missing (Figure $1)$.

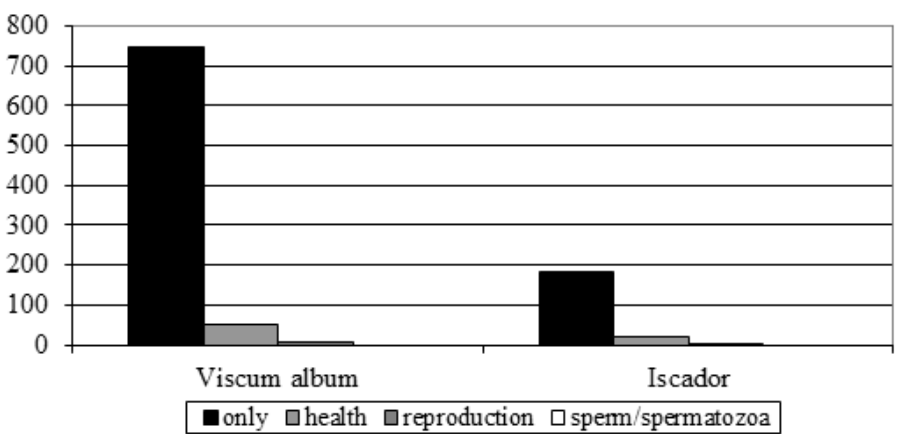

Figure 1 The occurrence/number ( $\mathrm{Y}$-axis) of articles related to Iscador and Viscum album related to health, reproduction and spermatozoa in PubMed (09/2018).

The target of our in vitro experiment was to describe the effect of different doses of Viscum album pini during several time intervals $(0-3 \mathrm{~h})$ on the fine parameters of rabbit spermatozoa motility and viability.

\section{MATERIAL AND METHODS}

\section{Animals, semen samples and in vitro culture}

Male breeding rabbits $(\mathrm{n}=10$; New Zealand White) kept under standard conditions at the experimental breeding and production centre (Animal Production Research Centre Nitra, Slovak Republic) were selected on the basis of age normally associated with reproduction (12-14 months). Rabbits were kept in a partially air-conditioned area under a photoperiod 16L:8D (minimum light intensity of 80 lux). Animals were housed in single cages, fed with a usual diet and were the water was available ad libitum. The air temperature was $20 \pm 2^{\circ} \mathrm{C}$ and relative humidity $70 \pm 5 \%$. Conditions of their care, manipulations and use corresponded to the instruction of EC no. 178/2002 and related EC documents, and were approved by local ethics committee.

Semen samples in five replicates were collected (early in the morning) on a single day with the help of artificial vagina (Kročková et al., 2012; Parkányi $\boldsymbol{e t}$ al., 2015). Promptly after collection the single semen showing a clear white colour without contain of gel and artificial particles, were processed to acquire pooled sample. The spermatozoa concentration in semen was $0.40-0.63 \times 10^{9}$ per $\mathrm{mL}$. The obtained semen samples were diluted according to routine methods (Chrenek et al., 2007; Roychoudhury and Massányi, 2008).

Later the spermatozoa were incubated in thermostat $\left(37 \pm 0.5^{\circ} \mathrm{C}\right)$ with various concentrations of Viscum album pini (Iscador P; Weleda, Verein für Krebsforschung Institute Hiscia - Arlesheim, Switzerland) dissolved in physiological solution. The control (PK) group used in the study was diluted only with physiological solution. The organization of experiments is listed in Table 1.

Table 1 Concentrations of Viscum album pini used in the study

\begin{tabular}{ccccc} 
Group & $\begin{array}{c}\text { Semen } \\
(\mu \mathrm{L})\end{array}$ & Iscador P $(\mu \mathrm{L})$ & $\begin{array}{c}\text { Physiological } \\
\text { solution }(\mu \mathrm{L})\end{array}$ & $\begin{array}{c}\text { Concentration } \\
\text { of Iscador P in } \\
\text { samples }(\mathrm{mg})\end{array}$ \\
\hline
\end{tabular}

\begin{tabular}{|c|c|c|c|c|c|}
\hline $\begin{array}{c}\text { PK - } \\
\text { control }\end{array}$ & 100 & 0 & 0 & 300 & 0 \\
\hline PA & 100 & 300 & \multirow{3}{*}{$\begin{array}{c}\text { Iscador P } \\
1 \mathrm{mg}\end{array}$} & 0 & 1.0 \\
\hline PB & 100 & 200 & & 100 & 0.66 \\
\hline PC & 100 & 100 & & 200 & 0.33 \\
\hline PD & 100 & 300 & \multirow{3}{*}{$\begin{array}{c}\text { Iscador P } \\
0.1 \mathrm{mg}\end{array}$} & 0 & 0.1 \\
\hline $\mathrm{PE}$ & 100 & 200 & & 100 & 0.066 \\
\hline PF & 100 & 100 & & 200 & 0.033 \\
\hline
\end{tabular}

viscotoxin $160 \mu \mathrm{g} / \mathrm{mL}$ (Podlech et al., 2012)

\section{Computer-assisted semen analysis}

Spermatozoa motility was used as an indicator of semen quality. The motility analysis was carried out using a CASA (Computer Assisted Semen Analyzer) system-Sperm Vision $^{\mathrm{TM}}$ program (MiniTub, Tiefenbach, Germany) with the
Olympus BX 51 microscope (Olympus, Tokyo, Japan) at cultivation times $0,1,2$ and 3 hours (Time $0-3$ ). Each sample was placed into the Makler Counting Chamber (depth $10 \mu \mathrm{m}$, Sefi-Medical Instruments, Haifa, Israel (Massányi et al., 2008). This study was performed in five replicates at each concentration. At least 1000 spermatozoa were analyzed in each sample (Lukáč et al., 2013). For the analysis a specific set up for rabbit semen was used and the selected parameters were analysed - total motility (MOT; \%), progressive motility (PRO; \%), distance average path (DAP; $\mu \mathrm{m})$, distance curved line (DCL; $\mu \mathrm{m})$, distance straight line (DSL; $\mu \mathrm{m}$ ), average path velocity (VAP; $\mu \mathrm{m} / \mathrm{s})$, velocity curved line $(\mathrm{VCL} ; \mu \mathrm{m} / \mathrm{s})$, velocity straight line (VSL; $\mu \mathrm{m} / \mathrm{s})$, straightness (STR), linearity (LIN), wobble (WOB), amplitude of lateral head displacement (ALH; $\mu \mathrm{m})$ and beat-cross frequency (BCF; Hz) as described previously (Roychoudhury $\boldsymbol{e t}$ al., 2010; Tvrdá et al., 2015; Adamkovičová et al., 2016; Paál et al., 2016)

\section{Viability analysis - MTT test}

Viability of rabbit spermatozoa cultured with Viscum album pini was evaluated by the metabolic activity (MTT) assay after 3 hours of culture. This colorimetric assay measures the conversion of 3-(4.5-dimetylthiazol-2-yl)-2.5diphenyltetrazolium bromide (MTT; Sigma-Aldrich, St. Louis, USA) to purple formazan particles by mitochondrial succinate dehydrogenase of intact mitochondria of living cells. Formazan was measured spectrophotometrically by a microplate ELISA reader (Multiskan FC, ThermoFisher Scientific, Finland). The data are expressed in percentage of control. Results from the analysis were collected during four repeated experiments for each concentration (Slanina et al., 2016).

\section{Viability - membrane integrity - Eosin-nigrosin}

The spermatozoa viability was evaluated using eosin-nigrosin staining methods (Slanina et al., 2018). From all the samples smears were prepared after 3 hours of culture. Experimental samples and the control sample were diluted in the ratio $1: 2$ : 2 with $5 \%$ eosin (Eosin Y) and 10\% nigrosin (Nigrosin) solution (both Sigma-Aldrich). For each slide 300 cells were counted under a light microscope (1000×, Leica DMIL LED; Leica Microsystems CMS GmbH, Germany) and classified as viable (intact membrane) and dead (damaged membrane). The experiment was realized in six replicates. The results of viability evaluation were expressed as the percentage of viable and dead spermatozoa (in \%).

\section{Acrosomal integrity}

The acrosomal status was assessed after 3 hours of culture following the fast green-rose Bengal staining protocol designed by Pope $\boldsymbol{e t}$ al. (1991). This singlestep staining method applies a mixture consisting of $1 \%$ fast green (SigmaAldrich), $1 \%$ rose bengal (Sigma-Aldrich) and 40\% ethyl alcohol (Centralchem, Bratislava, Slovak Republic) in $0.1 \mathrm{M}$ citric acid $-0.2 \mathrm{M}$ disodium phosphate buffer (Sigma-Aldrich). Twenty microliters of the thawed sample were mixed with $20 \mu \mathrm{l}$ of the staining solution and incubated for $70 \mathrm{~s}$ at room temperature. Ten microliters of the mixture were smeared on a tempered glass slide and airdried at $37^{\circ} \mathrm{C}$. Acrosomal integrity was evaluated using bright field microscopy at $1000 \times$ using oil immersion. At least 200 cells per slide were evaluated for the presence or absence of acrosome, and expressed as a percentage rate (Tvrdá $\boldsymbol{e t}$ al., 2017).

\section{Statistical analysis}

The control group (medium without Viscum album pini) was compared to the experimental groups. Statistical analysis was done by the GraphPad Prism program (version 3.02 for Windows; GraphPad Software, La Jolla California USA). For the analysis the descriptive statistical parameters (mean, standard error) were primary evaluated. One-way ANOVA with Dunnett's post-test was used for statistical evaluations. The level of significance was estimated at $* * *(\mathrm{p}<0.001), * *(\mathrm{p}<0.01)$ and $*(\mathrm{p}<0.05)$. For individual measurements average value $(\mathrm{x})$, minimum $(\mathrm{min})$ and maximum $(\max )$ value, standard deviation $(\mathrm{SD})$ and coefficient of variation (CV) were recorded.

\section{RESULTS AND DISCUSSION}

\section{Spermatozoa motility}

The initial spermatozoa motility (Time 0 ) showed decreased value for all doses of Viscum album pini in comparison to the control group, but only significant decrease was observed $(\mathrm{p}<0.01)$ in the sample PD $(73.04 \pm 8.70 \%)$ compared to control $(87.78 \pm 5.69 \%)$. After $1 \mathrm{~h}$ of the culture the average spermatozoa motility in control group $(78.47 \pm 12.51 \%)$ was very similar as in all experimental groups $(73.28-83.85 \%)$ and no significant differences were found. After 2 hours of in vitro cultivation no significant differences were found, but all values in experimental groups were higher compared to control. After 3 hours of in vitro cultivation interesting but not significant tendency of spermatozoa motility 
increase was found. Only in the groups with the highest Iscador P concentration (PA) a non-significant decrease was detected (Figure 2).

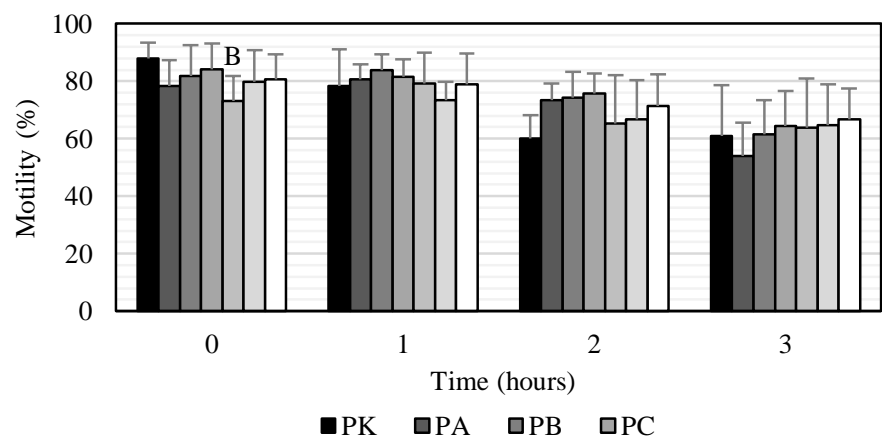

Figure 2 The effect of Viscum album pini on the total spermatozoa motility (in $\%)$, B $-\mathrm{p}<0.01$.

\section{Progressive spermatozoa motility}

At the beginning of the experiment (Time 0) the average progressive spermatozoa motility was decreased in all experimental groups compared to the control $(76.78 \pm 8.15 \%)$, but a significant values were detected only in group PD After 1 hour of culture the progressive spermatozoa motility was in the control group (PK) $67.38 \pm 15.53 \%$ and no significant differences were observed in experimental groups. After 2 hours of in vitro culture the progressive spermatozoa motility was higher in all groups with addition of Iscador P, but the differences were not significant. After 3 hours of culture for groups with lower Iscador $\mathrm{P}$ concentration (PD and (PE) similar values were found, and in groups with higher Iscador P (PA, PB, PD, PD) non-significant decrease was evident (Figure 3).

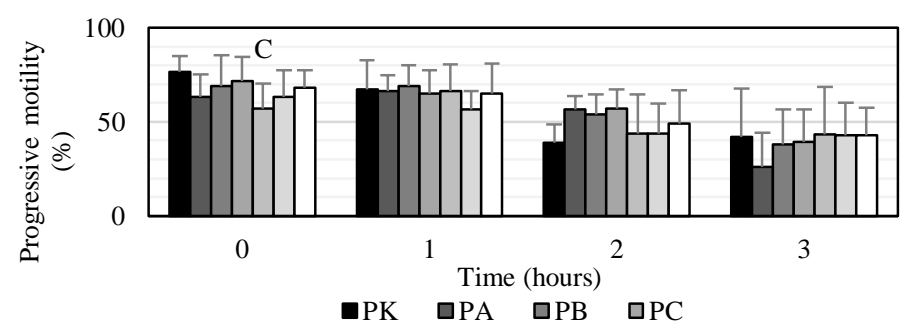

Figure 3 The effect of Viscum album pini on the progressive spermatozoa motility (in \%), $\mathrm{C}-\mathrm{p}<0.001$.

\section{Distance parameters}

Spermatozoa distance average path was not significantly affected at Time 0 and the values were in range $25.18-29.64 \mu \mathrm{m}$ (Figure 4 ). Very slightly lower values were detected after 1 hour of culture as well as after 2 hours of culture. At Time 3 not significant decrease was found in groups with higher Viscum album pini concentration (PA: $16.18 \pm 6.48 \mu \mathrm{m}$; PB: $18.53 \pm 4.96 \mu \mathrm{m}$; PC: $18.87 \pm 5.28 \mu \mathrm{m}$; $19.83 \pm 6.98 \mu \mathrm{m})$ compared to control $(21.43 \pm 9.43 \mu \mathrm{m})$. Similar tendency was found also for distance curved line and distance straight line (Figure 5, 6).

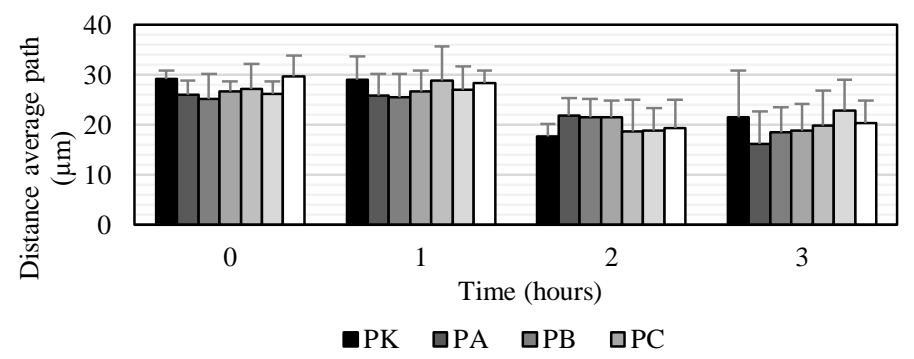

Figure 4 The effect of Viscum album pini on the spermatozoa distance average path $(\mu \mathrm{m})$.

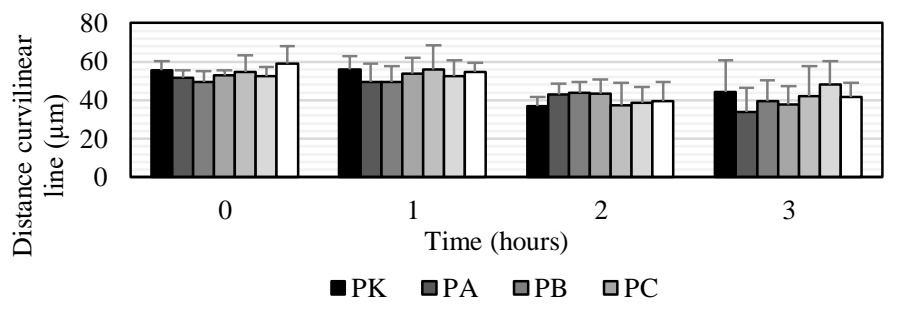

Figure 5 The effect of Viscum album pini on the spermatozoa distance curvilinear line $(\mu \mathrm{m})$.

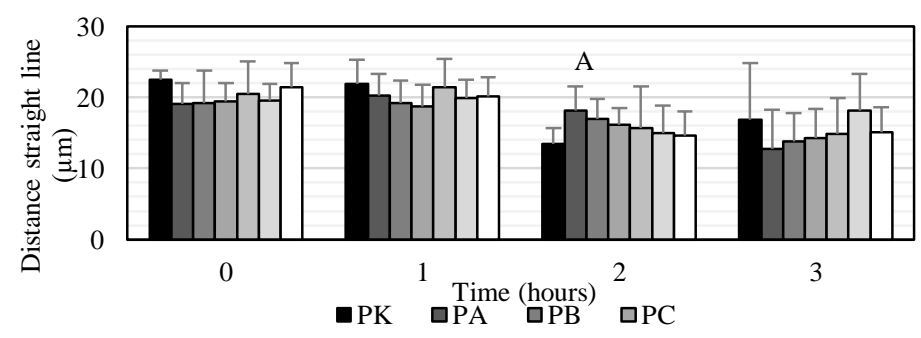

Figure 6 The effect of Viscum album pini on the spermatozoa distance straight line $(\mu \mathrm{m}), \mathrm{A}-\mathrm{p}<0.05$

\section{Velocity parameters}

At Time 0 the spermatozoa velocity average path was the highest in control group $(69.58 \pm 3.88 \mu \mathrm{m} / \mathrm{s})$ and lower values were detected in experimental groups $(58.32-67.97 \mu \mathrm{m} / \mathrm{s})$. Significant differences were found in experimental group $\mathrm{PB}$ in velocity average path (VAP) as well as in velocity curvilinear line (VCL) at time 0 (Figure 7,8 ). After 1 hour of culture the values were very similar in all groups $(59.52-68.27 \mu \mathrm{m} / \mathrm{s})$. At Time 2 , interestingly, all values were higher $(43.40-50.83 \mu \mathrm{m} / \mathrm{s})$ in Viscum album pini groups compared to control $(41.13 \pm 6.32 \mu \mathrm{m} / \mathrm{s})$, but the differences were not significant. At the end of the experiment the lowest velocity average path was found in group with the highest Viscum album pini concentration $(37.77 \pm 14.96 \mu \mathrm{m} / \mathrm{s})$ and difference compared to control was $11.91 \mu \mathrm{m} / \mathrm{s}$ (Figure 7). The values of spermatozoa velocity curvilinear and straight line showed very similar tendency (Figure 8,9 ).

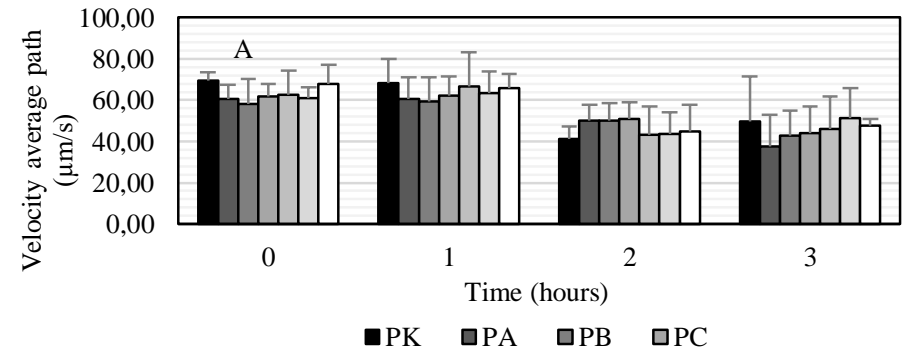

Figure 7 The effect of Viscum album pini on the spermatozoa velocity average path $(\mu \mathrm{m} / \mathrm{s}), \mathrm{A}-\mathrm{p}<0.05$.

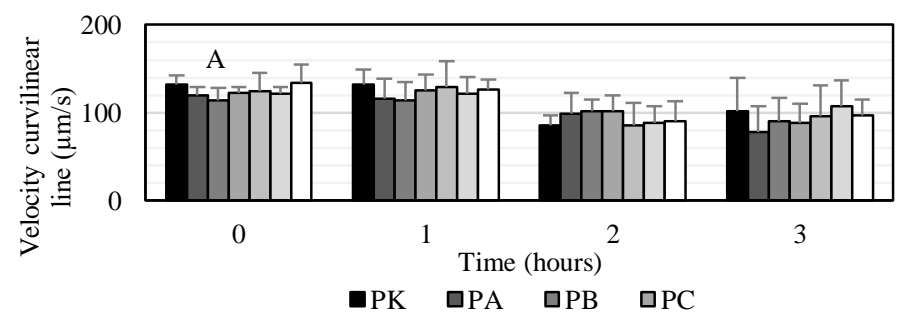

Figure 8 The effect of Viscum album pini on the spermatozoa velocity curvilinear line $(\mu \mathrm{m} / \mathrm{s}), A-p<0.05$.

Figure 9 The effect of Viscum album pini on the spermatozoa velocity straight line $(\mu \mathrm{m} / \mathrm{s})$. 


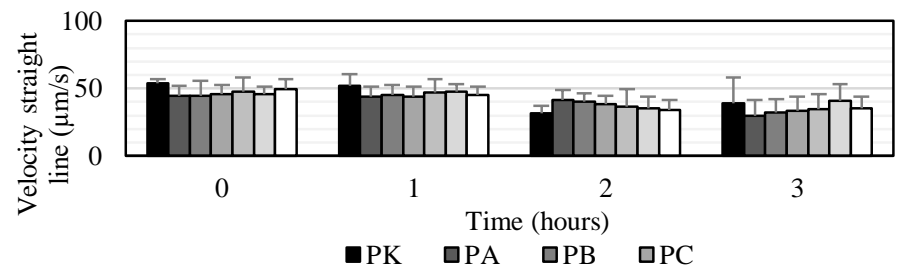

Figure 9 The effect of Viscum album pini on the spermatozoa velocity straight line $(\mu \mathrm{m} / \mathrm{s})$.

Other fine motility parameters

For selected motility ratios - spermatozoa straightness and wobble any dose and/or time dependent significant positive or negative effects were found (Figure 10, 12). After one hour of incubation linearity (VSL/VCL) showed significant difference in experimental group PC.

The initial amplitude of lateral head displacement (ALH) was 4.23 - $4.82 \mu \mathrm{m}$ with the highest value detected in control group (PK). At Time 1 no significan differences were found. After 2 hours of culture the amplitude of lateral head displacement decreased in all groups but was very similar $(3.31-4.08 \mu \mathrm{m})$. At the final stage of the experiment (Time 3) the decrease of ALH in comparison with control $(3.95 \pm 0.67 \mu \mathrm{m})$ was most evident in the group with the highest Icador P concentration (group PA: $3.19 \pm 0.80 \mu \mathrm{m}$ ) but the difference was not significant (Figure 13).

Values of beat cross frequency (BCF) completely confirm previous data. At Time 0,1 and 2 the values showed any significant difference. Also at Time 3 there were no significant differences and the difference between the control group (PK) and the group with the highest Viscum album pini was in average only $3.37 \mathrm{~Hz}$ (Figure 14).

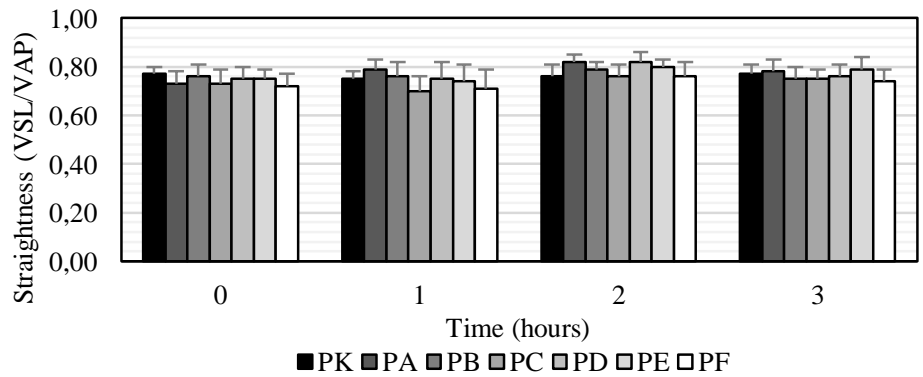

Figure 10 The effect of Viscum album pini on the spermatozoa straightness.

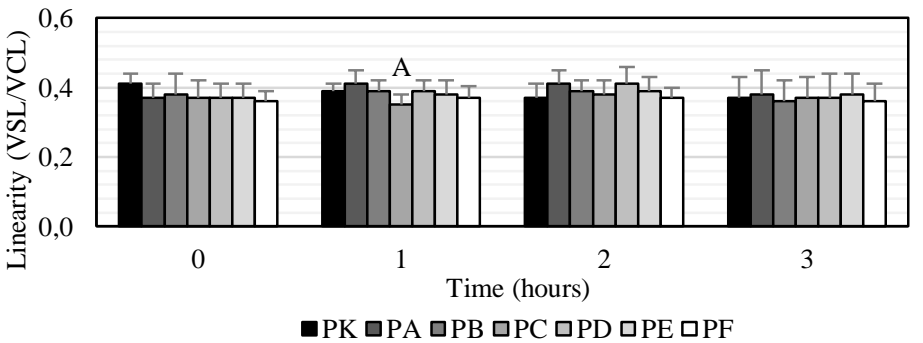

Figure 11 The effect of Viscum album pini on the spermatozoa linearity, A $\mathrm{p}<0.05$.

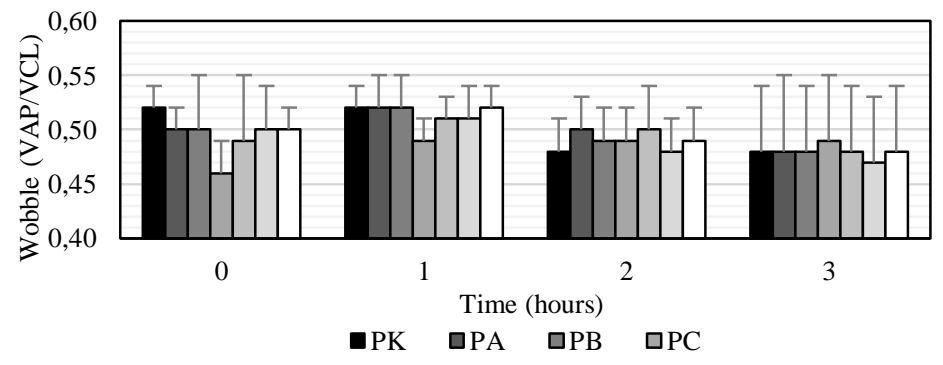

Figure 12 The effect of Viscum album pini on the spermatozoa wobble.

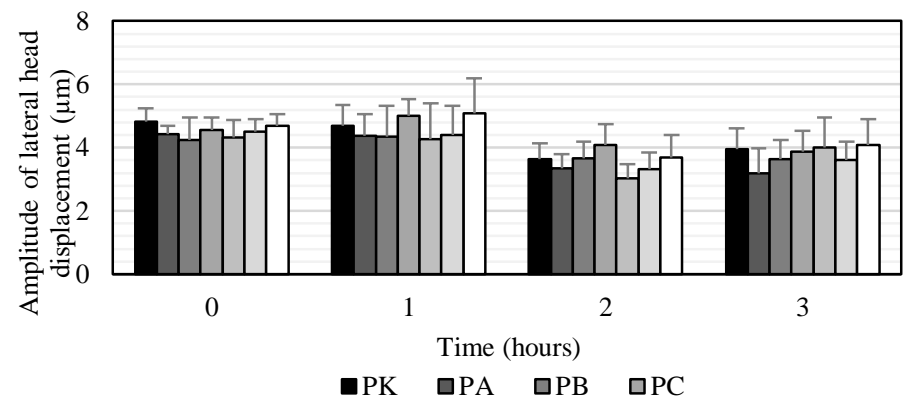

Figure 13 The effect of Viscum album pini on the amplitude of spermatozoa lateral head displacement $(\mu \mathrm{m})$.

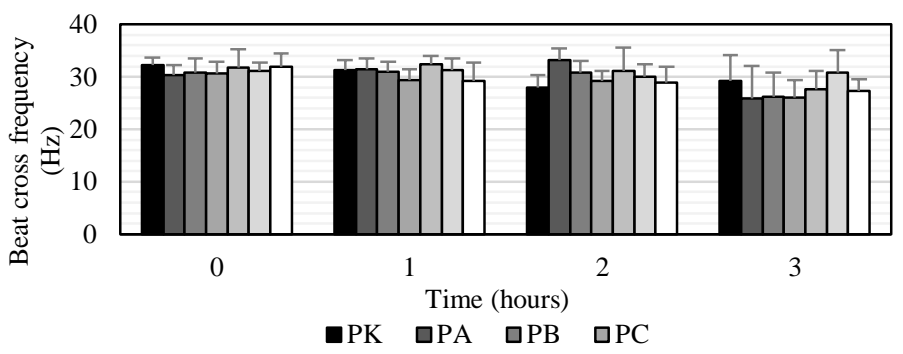

Figure 14 The effect of Viscum album pini on the spermatozoa beat cross frequency $(\mathrm{Hz})$

\section{Viability, Membrane integrity, Acrosomal integrity}

After 3 hours of incubation, viability of rabbit spermatozoa showed decreased values in all doses of Viscum album pini in comparison to the control group. The lowest value (75.69 $\pm 3.90 \%)$ was detected in group PA (Figure 15).

\section{MTT [\%]}

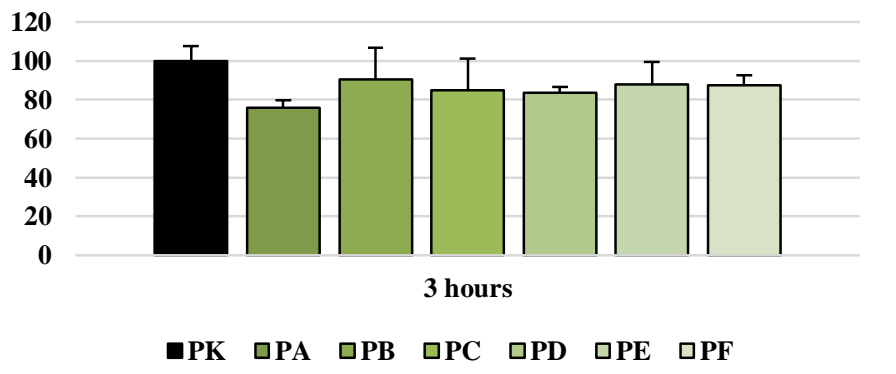

Figure 15 The effect of Viscum album pini on the viability (\%) of rabbit spermatozoa after 3 hours of incubation

Significant decrease $(\mathrm{p}<0.01)$ of membrane integrity (intact) was found in group PA $(58.67 \pm 9.60 \%)$ compared to control group (PK) $(81.33 \pm 4.96 \%)$. Also, in groups $\mathrm{PB}, \mathrm{PC}, \mathrm{PD}$ lower values in comparison to control group were detected. Only in groups PE and PF higher membrane integrity (intact, \%) than in the control group were found, but without significant evident (Figure 16).

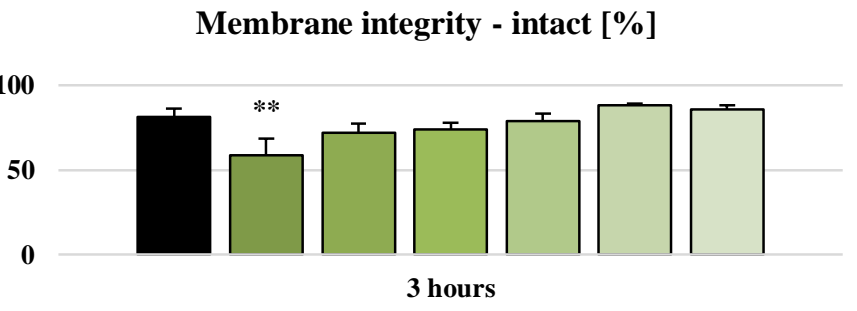

$\square$ PK $\square$ PA $\square$ PB $\square$ PC $\square$ PD $\square$ PE $\square$ PF

Figure 16 The effect of Viscum album pini on the membrane integrity (\%) of rabbit spermatozoa assessed after 3 hours of incubation. The level of significance was set at $* * \mathrm{P}<0.01$. 
The values of acrosomal integrity showed very similar tendency in all experimental groups. Acrosomal integrity in control group $(94.0 \pm 1.73 \%$ ) detected lower value in comparison to experimental groups (PA: 96.67 \pm 3.06 ; PB: $97.33 \pm 2.08 ; \quad$ PC: $96.33 \pm 1.15 ; \quad$ PD: $96.33 \pm 1.53 ; \quad$ PE: $96.33 \pm 0.58$; $\quad$ PF: $97.33 \pm 1.53 \%)$.

Anticancer preparations made from plants have been an object of scientific interest for many years. It is worth noting that as many as $25 \%$ of cytostatics used in the anticancer chemotherapy are obtained from plants (Greń and Massányi, 2016).

Extracts of the European mistletoe (Viscum album L.) have been widely used for decades as alternative, complementary treatment and adjuvant cancer therapy (Kovacs et al., 2006). In clinical practice mistletoe therapy is often given concomitantly to conventional chemotherapy. Iscador is extracted from mistletoe plants growing on different host trees, like apple, oak, or pine. Cytotoxic glycoproteins, the mistletoe lectins, are active component of mistletoe extracts and can stimulate effector cells of the innate and adaptive immune system (Stein et al., 2002; Braedel-Ruoff, S. 2010; Greń and Formicki, 2013). Experiments also indicate a statistically significant increase in albumin fraction level and lymphocyte count. Moreover, decrease of the total protein content, protein fractions globulins alpha2, beta, gamma and neutrophil, monocyte count in mouse serum was observed (Greń, 2009).

Various studies clearly report that the reproductive ability and the semen quality in various animal species is influenced by various environmental causes, age, stress, hormonal status, nutrition as well as toxins (Mangelsdorf $\boldsymbol{e t}$ al., 2003; Lukáč et al., 2011; Mousa-Balabel and Mohamed, 2011; Fallas-López et al. 2011) and according to this statement the target of this study was aimed on effect of Viscum album pini on spermatozoa motility in vitro experiment. Our results detected any dose and/or time dependent significant effect on rabbit spermatozoa. In the many years, following the increased success rate of cancer treatments, great efforts have been made to improve quality of life in survivors, including fertility preservation in young patients. Because of their gonadotoxic effects, chemo- and radiotherapy can temporarily or permanently compromise fertility (Di Bisceglie et al., 2013). Oncological treatments present severe gonadotoxic effects on both germ and Leydig cells. Of note, in a significant percentage of patients $(20-50 \%)$ spermatogenesis is impaired even before cancer treatments, probably due to the malignancy itself. The recovery of normal spermatogenesis after treatment may require several years, and mainly depends on various factors - initial spermatozoa count, type and dose of specific oncological treatments and patient age. Disturbance of homeostasis of reproductive system in the some diseases can be seen from the decline in physical and chemical parameters of spermatozoa, such as $\mathrm{pH}$, semen volume, concentration, motility, and the percentage of spermatozoa viability. These data justify the increasing efforts in identifying prevention and treatment strategies to preserve reproductive functions in young men with malignancies (Colpi et al., 2004; Maltaris et al., 2006).

Researchers are unanimous about the negative impact of various factors on male reproduction and spermatozoa quality (Burton, 2013; Lukáč et al., 2013; Lukáčová et al., 2015). The mechanisms underlying the male infertility of Viscum album (Iscador) extracts have not been investigated.

An in vitro study investigated the effect of a standardized mistletoe preparation on the action of Trastuzumab, a drug used for the treatment of Her-2 positive breast cancer. Clear dose dependent anti-proliferative action of Viscum album exctract (VAE) was found at concentrations $\geq 10 \mu \mathrm{g} / \mathrm{ml}$ after 3 days of culture (Weissenstein et al., 2016). Effects of Viscum album quercus extract in different concentrations were also studied in an in vitro study with cancer cells: three multiple myeloma (MM) cell lines (OPM-2, RPMI-8226, U-266) and three B cell lymphoma cell lines (U-698, DOHH-2, WSU-1). Viscum album/Qu extract clearly decreased the membrane expression of IL-6R and gp130 in RPMI-8226 (down to $29 \%$ and $32 \%$ ) and the expression of gp130 in WSU-1 (down to 22\%). A significant decrease of viable cells of RPMI-8226 (down to 28\%) and WSU-1 (down to $8 \%$ ) at $100 \mu \mathrm{g} / 10^{6} \mathrm{cells} / \mathrm{ml}$ was detected. There was a fine correlation between the inhibition of proliferation and viability. VA Qu was more effective in cells having a high proliferation rate than in those with a low proliferation rate (Kovacs et al., 2006). Our observations indicate that Iscador in concentration analyzed in this report does not effects the spermatozoa motility, progressive spermatozoa motility and some other fine spermatozoa motility parameters (velocity curved line, amplitude of lateral head displacement and beat cross frequency).

There are some reports about negative effect of Iscador $\mathrm{Qu}$ on reproductive ability. Mistletoe lectins have been identified as main active components and exhibit cytotoxic effects. A relationship between diminished spermatozoa quality and anticancer treatment may be a result of a series of cascade events that cause a fall in intracellular ATP levels (Luria et al., 2002; Turner, 2006; Storey, 2008), release of different apoptogenic factors (as pro-caspases, cytochrome $C$, and apoptosis inducing factor) (Casao et al., 2015) from mitochondria into the cytosol through disruption of mitochondrial membrane, inactivation of some biochemical pathways, enzyme dysfunction, disturbed axonemal protein phosphorylation, increased membrane permeability and generation of spermicidal products, which have adverse effects on the spermatozoa functions. Similarly, the spermatozoa motility is also reduced by ergonovine (Tash and Means, 1982, Gallagher and Senger, 1989), and the ergot alkaloids induce motility changes in bovine sperm cells by interacting with alpha-adrenergic receptors (Wang $\boldsymbol{e t}$ al., 2009).

\section{CONCLUSION}

The results of this study indicate that spermatozoa are a useful in vitro model for the biological evaluation of chemicals providing quantitative as well as qualitative data. In conclusion, the present study shows the Viscum album pini exactly in these concentrations and in vitro conditions have no negative effect on spermatozoa motility and viability characteristics.

Acknowledgments: This work was supported by projects VEGA 1/0539/18, APVV-15-0543, APVV-16-0289 and KEGA 010/SPU-4/2018. The research leading to these results has received funding from the European Community under project no 26220220180: Building Research Centre “AgroBioTech”.

\section{REFERENCES}

ADAMKOVIČOVÁ, M., TOMAN, R., MARTINIAKOVÁ, M., OMELKA, R., BABOŠOVÁ, R., KRAJČOVIČOVÁ, V., ... MASSÁNYI, P. (2016). Sperm motility and morphology changes in rats exposed to cadmium and diazinon. Reproductive Biology and Endocrinology, 14(1). https://doi.org/10.1186/s12958016-0177-6

BRAEDEL-RUOFF, S. (2010). Immunomodulatory Effects of Viscum album extracts on natural killer cells: Review of clinical trials. Forschende Komplementärmedizin / Research in Complementary Medicine, 17(2), 63-73. https://doi.org/10.1159/000288702

BURTON, A. (2013). Study suggests long-term decline in fresh sperm quality Environmental Health Perspectives, 121(2). https://doi.org/10.1289/ehp.121-a46 BÜSSING, A. (2006). Immune modulation using mistletoe (Viscum album L.) extracts Iscador. Arzneimittelforschung, 56(06), 508-515. https://doi.org/10.1055/s-0031-1296818

BÜSSING, A., BÜCKNER, U., ENSER-WEIS, U., SCHNELLE, M., SCHUMANN, A., SCHIETZEL, M., ... HACKMANN, J. (2008). Modulation of chemotherapy-associated immunosuppression by intravenous application of Viscum album L. Extract (Iscador): A randomised phase II study. European Journal of Integrative Medicine, 1, 2-3. https://doi.org/10.1016/i.eujim.2008.08.084

CASAO, A., MATA-CAMPUZANO, M., ORDÁS, L., CEBRIÁN-PÉREZ, J. MUIÑO-BLANCO, T., \& MARTÍNEZ-PASTOR, F. (2015). Cleaved PARP-1, an apoptotic marker, can be detected in ram spermatozoa. Reproduction in Domestic Animals, 50(4), 688-691. https://doi.org/10.1111/rda.12549

CHRENEK, P., TRANDŽÍK, J., MASSÁNYI, P., MAKAREVICH, A., LUKÁČ N., PEŠKOVIČOVÁ, D., \& PALEYANDA, R. (2007). Effect of transgenesis on reproductive traits of rabbit males. Animal Reproduction Science, 99(1-2), 127 134. https://doi.org/10.1016/i.anireprosci.2006.04.052

COLPI, G. M., CONTALBI, G. F., NERVA, F., SAGONE, P., \& PIEDIFERRO, G. (2004). Testicular function following chemo-radiotherapy. European Journal of Obstetrics \& Gynecology and Reproductive Biology, 113, S2-S6. https://doi.org/10.1016/j.ejogrb.2003.11.002

CRAVOTTO, G., BOFFA, L., GENZINI, L., \& GARELLA, D. (2010) Phytotherapeutics: An evaluation of the potential of 1000 plants. Journal of Clinical Pharmacy and Therapeutics, 35(1), 11-48. https://doi.org/10.1111/j.1365-2710.2009.01096.x

DEHGHAN, M. H., MARTIN, T., \& DEHGHANAN, R. (2005). Antifertility effect of Iranian neem seed alcoholic extract on epididymal sperm of mice. Iranian Journal of Reproductive Medicine, 3(2), 83-89.

DI BISCEGLIE, C., BERTAGNA, A., COMPOSTO, E. R., LANFRANCO, F., BALDI, M., MOTTA, G., ... MANIERI, C. (2013). Effects of oncological treatments on semen quality in patients with testicular neoplasia or lymphoproliferative disorders. Asian Journal of Andrology, 15(3), 425-429. https://doi.org/10.1038/aja.2012.171

EVANS, M., BRYANT, S., HUNTLEY, A. L., \& FEDER, G. (2016). Cancer patients' experiences of using mistletoe (Viscum album): A qualitative systematic review and synthesis. The Journal of Alternative and Complementary Medicine, 22(2), 134-144. https://doi.org/10.1089/acm.2015.0194

FALLAS-LÓPEZ, M., RODRÍGUEZ-DE LARA, R., BÁRCENA-GAMA, R., SÁNCHEZ-TORRES ESQUEDA, M. T., HERNÁNDEZ-SÁNCHEZ, D., MARTÍNEZ-HERNÁNDEZ, P. A., \& AGUILAR-ROMERO, O. (2011). Rabbi sexual behavior, semen and sperm characteristics when supplemented with sprouted wheat. Animal Reproduction Science, 129(3-4), 221-228. https://doi.org/10.1016/i.anireprosci.2011.12.009

GALLAGHER, G. R., \& SENGER, P. L. (1989). Effect of phenylephrine, ergonovine, oxytocin and norepinephrine as an extender ingredient on viability of bovine spermatozoa. Journal of Animal Science, 67(6), 1573. https://doi.org/10.2527/jas1989.6761573x

GARDIN, N. E. (2009). Immunological response to mistletoe (Viscum albumL.) in cancer patients: a four-case series. Phytotherapy Research, 23(3), 407-411. https://doi.org/10.1002/ptr.2643 
GREŃ, A. (2009). Effects of Iscador preparations on the reactivity of mouse immune system. Neuro endocrinology letters, 30(4), 530-534.

GREŃ, A., FORMICKI, G., STAWARZ, R., GUZIK ,M. (2011). The effect of plant preparations on selected parameters of oxidative stress in animal models of diabetes mellitus. Journal of Physiology and Pharmacology, 62: 128.

GREŃ, A., \& FORMICKI, G. (2013). Effects of Iscador and Vincristine and 5Fluorouracil on brain, liver, and kidney element levels in alloxan-induced diabetic mice. Biological Trace Element Research, 152(2), 219-224. https://doi.org/10.1007/s12011-013-9608-9

GREŃ, A., MASSÁNYI, P. (2016). Antidiabetic and antioxidant potential of plant extracts. Nitra: Slovak University of Agriculture, Nitra, pp. 125. ISBN 97880-552-1524-2

HAJTO, T., FODOR, K., PERJESI, P., \& NEMETH, P. (2011). Difficulties and perspectives of immunomodulatory therapy with mistletoe lectins and standardized mistletoe extracts in evidence-based medicine. Evidence-Based Complementary and Alternative Medicine, 2011, 1-6. https://doi.org/10.1093/ecam/nep191

HEGDE, P., MADDUR, M. S., FRIBOULET, A., BAYRY, J., \& KAVERI, S. V. (2011). Viscum album exerts anti-inflammatory effect by selectively inhibiting cytokine-induced expression of cyclooxygenase-2. PLoS ONE, 6(10), e26312. https://doi.org/10.1371/journal.pone.0026312

KARUNAKARAN, U., \& PARK, K. G. (2013). A systematic review of oxidative stress and safety of antioxidants in diabetes: Focus on islets and their defence. Diabetes \& Metabolism Journal, 37(2), 106 https://doi.org/10.4093/dmj.2013.37.2.106

KOVACS, E., LINK, S., \& TOFFOL-SCHMIDT, U. (2006). Cytostatic and cytocidal effects of mistletoe (Viscum album L.) quercus extract Iscador. Arzneimittelforschung, 56(06), 467-473. https://doi.org/10.1055/s-0031-1296814 KROČKOVÁ, J., MASSÁNYI, P., TOMAN, R., DANKO, J., \& ROYCHOUDHURY, S. (2012). In vivo and in vitro effect of bendiocarb on rabbit testicular structure and spermatozoa motility. Journal of Environmental Science and Health, Part A, 47(9), 1301-1311. https://doi.org/10.1080/10934529.2012.672136

KUBISCH, H. M., WANG, J., BRAY, T. M., \& PHILLIPS, J. P. (1997) Targeted overexpression of $\mathrm{Cu} / \mathrm{Zn}$ superoxide dismutase protects pancreatic $\beta$ cells against oxidative stress. Diabetes, 46(10), 1563-1566. https://doi.org/10.2337/diacare.46.10.1563

LUKÁČ, N., BÁRDOS, L., STAWARZ, R., ROYCHOUDHURY, S., MAKAREVICH, A. V., CHRENEK, P., ... MASSÁNYI, P. (2011). In vitro effect of nickel on bovine spermatozoa motility and annexin V-labeled membrane changes. Journal of Applied Toxicology, 31, 2, 144-149. https://doi.org/10.1002/jat.1574

LUKÁČ, N., LUKÁČOVÁ, J., PINTO, B., KŇAŽICKÁ, Z., TVRDÁ, E., \& MASSÁNYI, P. (2013). The effect of nonylphenol on the motility and viability of bovine spermatozoa in vitro. Journal of Environmental Science and Health Part A, 48(8), 973-979. https://doi.org/10.1080/10934529.2013.762744

LUKÁČOVÁ, J., JAMBOR, T., KŇAŽICKÁ, Z., TVRDÁ, E., KOLESÁROVÁ, A., \& LUKÁČ, N. (2015). Dose- and time-dependent effects of bisphenol A on bovine spermatozoa in vitro. Journal of Environmental Science and Health, Part A, 50(7), 669-676. https://doi.org/10.1080/10934529.2015.1011963

LURIA, A., RUBINSTEIN, S., LAX, Y., \& BREITBART, H. (2002). Extracellular adenosine triphosphate stimulates acrosomal exocytosis in bovine spermatozoa via P2 purinoceptor1. Biology of Reproduction, 66(2), 429-437. https://doi.org/10.1095/biolreprod66.2.429

MALDACKER, J. (2006). Preclinical investigations with mistletoe (Viscum album L.) extract Iscador. Arzneimittelforschung, 56(06), 497-507. https://doi.org/10.1055/s-0031-1296817

MALTARIS, T., KOELBL, H., SEUFERT, R., KIESEWETTER, F., BECKMANN, M. W., MUELLER, A., \& DITTRICH, R. (2006). Gonadal damage and options for fertility preservation in female and male cancer survivors. Asian Journal of Andrology, 8(5), 515-533. https://doi.org/10.1111/j.1745-7262.2006.00206.x

MANGELSDORF, I., BUSCHMANN, J., \& ORTHEN, B. (2003). Some aspects relating to the evaluation of the effects of chemicals on male fertility. Regulatory Toxicology and Pharmacology, 37(3), 356-369. https://doi.org/10.1016/s02732300(03)00026-6

MASSÁNYI, P., CHRENEK, P., LUKÁČ, N., MAKAREVICH, A. V., OSTRÓ, A., ŽIVČÁK, J., \& BULLA, J. (2008). Comparison of different evaluation chambers for analysis of rabbit spermatozoa motility parameters using CASA system. Slovak Journal of Animal Science, 2, 60-66.

MOUSA-BALABEL, T. M., \& MOHAMED, R. A. (2011). Effect of different photoperiods and melatonin treatment on rabbit reproductive performance. Veterinary Quarterly, 31(4), 165-171. https://doi.org/10.1080/01652176.2011.642533

MODAK, M., DIXIT, P., LONDHE, J., GHASKADBI, S., PAUL, A., DEVASAGAYAM, T. (2007). Indian herbs and herbal drugs used for the treatment of diabetes. Journal of Clinical Biochemistry and Nutrition, 40: 163173.

MOSHER, W. D., \& PRATT, W. F. (1991). Fecundity and infertility in the United States: incidence and trends: The views expressed in this editorial are solely those of the authors and not necessarily those of the U.S. Department of Health and Human Services. Fertility and Sterility, 56(2), 192-193. https://doi.org/10.1016/s0015-0282(16)54469-0

NAZARUK, J., \& ORLIKOWSKI, P. (2016). Phytochemical profile and therapeutic potential of Viscum album L. Natural Product Research, 30(4), 373385

NAZIROGLU, M., \& CAY, M. (2001). Protective role of intraperitoneally administered vitamin $\mathrm{E}$ and selenium on the antioxidative defence mechanisms in rats with diabetes induced by streptozotocin. Biological Trace Element Research, 79(2), 149-159. https://doi.org/10.1385/bter:79:2:149

PAÁL, D., KROČKOVÁ, J., ONDRUŠKA, L., SLANINA, T., STREJČEK, F., \& MASSÁNYI, P. (2014). Effect of semen collection frequency on the progress in the motility of rabbit spermatozoa. Slovak Journal of Animal Science, 47, 2, 61-67.

PAÁL, D., STREJČEK, F., SLANINA, T., KOVÁČOVÁ, R., LUKÁČ, N., QOJA, A. O., ... MASSÁNYI, P. (2016). Crude glycerol negatively affects rabbit spermatozoa motility in vitro. Journal of the Hellenic Veterinary Medical Society, 67(4), 223. https://doi.org/10.12681/jhvms.15642

PARKÁNYI, V., ONDRUŠKA, L., MASSÁNYI, P., LUKÁČ, N. (2015). Effects of the HPA lectin on rabbit sperm motility and fertility. Slovak Journal of Animal Science, 48: 186.

PODLECH, O., HARTER, P. N., MITTELBRONN, M., PÖSCHEL, S., \& NAUMANN, U. (2012). Fermented mistletoe extract as a multimodal antitumoral agent in gliomas. Evidence-Based Complementary and Alternative Medicine, 2012, 1-15. https://doi.org/10.1155/2012/501796

POPE, C. E., ZHANG, Y. Z., \& DRESSER, B. L. (1991). A simple staining method for quantifying the acrosomal status of cat spermatozoa. Theriogenology, 35(1), 257. https://doi.org/10.1016/0093-691x(91)90233-4

RAFAY, J., \& PARKÁNYI, V. (2016). The rabbit as a model and farm animal at the Research Institute for Animal Production Nitra: A review. Slovak Journal of Animal Science, 2016, 4, 141-146.

ROYCHOUDHURY, S., \& MASSÁNYI, P. (2008). In vitro copper inhibition of the rabbit spermatozoa motility. Journal of Environmental Science and Health, Part A, 43(6), 651-656. https://doi.org/10.1080/10934520801893766

ROYCHOUDHURY, S., MASSÁNYI, P., SLAMEČKA, J., CHLEBEC, I., TRANDŽÍK, J., BULLA, J., ... \& AYOUB, M. A. (2009). In vitro gossypol induced spermatozoa motility alterations in rabbits. Journal of Environmental Science and Health Part B, 44(7), 730-741. https://doi.org/10.1080/03601230903163905

ROYCHOUDHURY, S., MASSÁNYI, P., BULLA, J., CHOUDHURY, M. D. STRAKA, L., LUKÁČ́, N., ... BÁRDOS, L. (2010). In vitro copper toxicity on rabbit spermatozoa motility, morphology and cell membrane integrity. Journal of Environmental Science and Health, Part A, 45(12), 1482-1491. https://doi.org/10.1080/10934529.2010.506092

SEIBERT, H., KOLOSSA, M., \& WASSERMANN, O. (1989). Bovine spermatozoa as anin vitro model for studies on the cytotoxicity of chemicals effects of chlorophenols. Cell Biology and Toxicology, 5(3), 315-330. https://doi.org/10.1007/bf01795359

SLANINA, T., KOVÁČOVÁ, R., LUKÁČ, N., \& MASSÁNYI, P. (2016) Impact of tilmicosin on the rabbit spermatozoa motility and viability. Journal of Microbiology, Biotechnology and Food Sciences, 05 (SI 1), 53-56. https://doi.org/10.15414/jmbfs.2016.5.special1.53-56

SLANINA, T., MIŠKEJE, M., TIRPÁK, F., BŁASZCZYK, M., STAWARZ, R., \& MASSÁNYI, P. (2018). Effect of taurine on turkey (Meleagris gallopavo) spermatozoa viability and motility. Czech Journal of Animal Science, 63, 4, 127135. https://doi.org/10.17221/79/2017-cjas

STEIN, G. M., BÜSSING, A., \& SCHIETZEL, M. (2002). Stimulation of the maturation of dendritic cells in vitro by a fermented mistletoe extract. Anticancer Research, 22(6C), 4215-4219.

STOREY, B. T. (2008). Mammalian sperm metabolism: oxygen and sugar, friend and foe. The International Journal of Developmental Biology, 52(5-6), 427-437. https://doi.org/10.1387/ijdb.072522bs

TASH, J. S., \& MEANS, A. R. (1982). Regulation of protein phosphorylation and motility of sperm by cyclic adenosine monophosphate and calcium. Biology of Reproduction, 26(4), 745-763. https://doi.org/10.1095/biolreprod26.4.745

TVRDÁ, E., LUKÁČ, N., LUKÁČOVÁ, J., JAMBOR, T., \& MASSÁNYI, P (2015). Dose- and time-dependent in vitro effects of divalent and trivalent iron on the activity of bovine spermatozoa. Biological Trace Element Research, 167(1), 36-47. https://doi.org/10.1007/s12011-015-0288-5

TVRDÁ, E., MACKOVICH, A., GREIFOVÁ, H., HASHIM, F., \& LUKÁČ, N. (2017). Antioxidant effects of lycopene on bovine sperm survival and oxidative profile following cryopreservation. Veterinární Medicína, 62(No. 8), 429-436. https://doi.org/10.17221/86/2017-vetmed

TURNER, R. M. (2006). Moving to the beat: A review of mammalian sperm motility regulation. Reproduction, Fertility and Development, 18(2), 25. https://doi.org/10.1071/rd05120

WANG, H., LOOPER, M. L., JOHNSON, Z. B., RORIE, R. W., \& ROSENKRANS, C. F. (2009). Involvement of signalling pathways in bovine sperm motility, and effect of ergot alkaloids. In Vitro Cellular \& Developmental Biology - Animal, 45(8), 483-489. https://doi.org/10.1007/s11626-009-9191-8 
WEISSENSTEIN, U., KUNZ, M., URECH, K., REGUEIRO, U., \&

BAUMGARTNER, S. (2016). Interaction of a standardized mistletoe (Viscum

album) preparation with antitumor effects of Trastuzumab in vitro. $B M C$

Complementary and Alternative Medicine, 16(1). https://doi.org/10.1186/s12906-

016-1246-2 